\title{
The participation of victims in the trial process
}

\author{
Liz HefFernaN ${ }^{1}$ \\ Trinity College Dublin
}

\begin{abstract}
Directive 2012/29/EU, establishing minimum standards on the rights, support and protection of victims of crime, forms part of a package of measures designed to ensure that victims have the same basic level of rights throughout the EU regardless of their nationality or the location of the crime. One of the Directive's innovations is a suite of measures designed to facilitate the participation of victims in the criminal process. The provisions include a right on the part of victims to be heard and a right to have their dignity protected when giving evidence.

Although there has been a gradual strengthening of victims' rights at national and international level, the concept of participation remains poorly defined and practice varies widely across the EU. The issue is particularly controversial in common law systems where victims are not assigned any formal role in the trial process. The traditional adversarial trial, designed to accommodate the prosecution and the defence, poses a structural obstacle to reform. However, recognising the limits of EU competence to legislate in the area of criminal justice, the member states have been afforded a wide margin of appreciation when implementing the Directive's provisions on participation.
\end{abstract}

Keywords: victims of crime; victim participation; adversarial trial; EU criminal law; special measures for witnesses; right to be heard

7 his article explores the implications of the emerging EU right to victim participation

1 for the adversarial trial process. The focus is Ireland, a common law country and EU member state in which the conduct of criminal proceedings is shaped by the personal rights guarantees of a written constitution. Through analysis of the Directive and Ireland's proposed legislation on point, the article considers in particular the evolving role of the victim as witness in the criminal trial.

\section{Introduction}

Recent decades have seen an increase in international cooperation and engagement in the field of criminal justice. The prevalence of transnational crimes such as terrorism, human trafficking and cybercrime has prompted governments to collaborate on common solutions. At the same time, the permeating effect of human rights has fostered the harmonisation of minimum standards across legal systems. These phenomena find particular expression in Europe and are reflected in a heightened emphasis on criminal

1 Associate Professor and Fellow, Trinity College Dublin. 
justice within the Council of Europe and the EU. It cannot be gainsaid that comparative criminal justice is exerting a discernible influence on the development of law and procedure at national level. However, the extent to which enhanced international engagement has fostered convergence among adversarial and inquisitorial systems remains a subject of debate. ${ }^{2}$

One area of criminal justice where the EU has played a heightened role is the crystallisation of legal standards on the position of victims of crime. Directive 2012/29/EU establishes minimum standards on the rights, support and protection of victims of crime ${ }^{3}$ and, as such, combines with other initiatives to ensure that 'any victim can rely on the same basic level of rights, whatever their nationality and wherever in the EU the crime takes place'. ${ }^{4}$ The Directive houses a wide range of concrete measures that speak to the experience of victims in the national systems of criminal justice.

The Directive's core policy objectives are to ensure that victims 'receive appropriate information, support and protection and are able to participate in criminal proceedings' ${ }^{5}$ Whereas the bulk of the provisions relate to support and protection, the present article explores the more ambiguous and controversial idea of victim participation. The discussion focuses on Ireland, a common law member state that has an independent constitutional tradition, and considers the likely impact of the Directive on the development of this aspect of Irish law and practice. Victim participation presents a particular challenge for the Irish legal system because victims do not play any formal part in the common law trial process. However, because there is considerable variation in the role of victims across the member states, the EU legislature has adopted a flexible stance on the transposition of national measures to give effect to the Directive's minimum standards on participation. ${ }^{6}$

The government's proposed transposition of the Directive is embodied in the Criminal Justice (Victims of Crime) Bill 2016 and it draws on this latitude in drafting legislative measures that would enhance opportunities for victim participation without altering the essentials of the current system. The government published a General Scheme of a Bill in July 2015 and a formal Criminal Justice (Victims of Crime) Bill as late as 27 December 2016..$^{7}$ The Directive has been in force since 16 November 2015 (the deadline for transposition $)^{8}$ and, in principle, has direct effect in Ireland. ${ }^{?}$

2 John D Jackson and Sarah J Summers, The Internationalisation of Criminal Evidence: Beyond the Common Law and Civil Law Traditions (CUP 2012) 5-7; Louise Ellison, The Adversarial Process and the Vulnerable Witness (Clarendon 2001) 142; Mirjan R Damaška, 'Evidentiary Barriers to Conviction and Two Models of Criminal Procedure: A Comparative Study' (1972-1973) 121 University of Pennsylvania Law Review 506.

3 Adopted by the European Parliament and Council on 25 October 2012, OJ L 325/57, 14/11/2012. The Directive replaces Framework Decision 2001/220/JHA on the standing of victims in criminal proceedings: Directive, Art 30. A victim, for purposes of the Directive is a natural person who has suffered physical, psychological or other harm as a direct result of a crime. However, the term also extends to a family member of a person whose death was directly caused by a crime and where the family member has suffered harm as a result: Directive, Art 2(1)(a).

4 European Commission, DG Justice Guidance Document (Brussels, 19 December 2013) 3.

5 Directive, Art 1.

6 Directive, Art 27(1).

7 No 121 of 2016, sponsored by the Minister for Justice and Equality. The present article was written before the very recent enactment of the Bill as the Criminal Justice (Victim of Crime) Act 2017, No 28 of 2017. The legislation has not yet been commenced.

8 Ireland is not obliged to participate in EU instruments relating to criminal justice but exercised its right under the Lisbon Treaty to opt in to the Directive: Directive, Recital 70 (referencing Treaty of Lisbon, Protocol 21, Art 3.1).

9 Case 47/74, Van Duyn [1974] ECR 1337; Case 148/78, Ratti [1979] ECR 1629. See also KD v DPP [2016] IEHC 21. 
It is essential to acknowledge at the outset that the Irish common law trial process is framed and operated by reference to the well-established rights of the defence under the Irish Constitution and international human rights law. It is a fundamental precept of our liberal democratic tradition that trials are conducted within a system calibrated to ensure that the accused is protected against the power of the state and the possibility of wrongful conviction. In particular, the Irish Constitution, the EU Charter and the European Convention on Human Rights (ECHR) expressly and robustly safeguard the right of an accused to a fair trial, a broad guarantee that shelters a panoply of substantive and procedural protections. ${ }^{10}$ Thus, any argument in favour of greater legal recognition of the role of victims in the process is necessarily complicated by the potential implications for the rights of the defence. ${ }^{11}$ As we shall see, the concept of victim participation has not yet crystallised into a clear-cut legal construct that would enable us to pinpoint with a degree of certainty where the individual's rights and the state's corresponding obligations begin and end. It is clear, nevertheless, that the role of the victim must co-exist with the position of the accused and, in particular, must evolve in a manner that respects the accused's right to a fair trial.

\section{The common law trial process}

In contrast to the position in some other member states, the victim has no official role or standing in the Irish common law trial process. ${ }^{12}$ The victim is neither a party to criminal proceedings nor represented independently as a general rule, and she does not give evidence in the proceedings as of right. ${ }^{13}$ Indeed, the design of the common law trial as a two-party system (dominated by the roles of the prosecution and the defence) presents a substantial structural obstacle to the very concept of victim participation. ${ }^{14}$

Although the victim's interests are presumptively aligned with the prosecution, the prosecution does not represent the victim in any formal sense. As the late Mr. Justice Carney observed:

Victims tend to instinctively feel that counsel appearing on behalf of the prosecution is 'their barrister' as they would put it. This is not the case and the

10 Constitution, Art 38(1); EU Charter, Art 47; ECHR, Art 6.

11 Jonathan Doak, Victims' Rights, Human Rights and Criminal Justice: Reconceiving the Role of Third Parties (Hart 2008) 246-7; Deirdre Duffy, "Balance" in the Criminal Justice System: Misrepresenting the Relationship between the Rights of Victims and Defendants' (2009) 19(1) Irish Criminal Law Journal 2.

12 See generally Shane Kilcommins and Luke Moffett, 'The Inclusion and Juridification of Victims on the Island of Ireland' in Deirdre Healy (ed), Routledge Handbook of Irish Criminology (Routledge 2016) 379; Ger Coffey, 'The Victim of Crime and the Criminal Justice Process' (2006) 3 Irish Criminal Law Journal 15; Mary Rogan, 'Victims' Rights: Theory and Practice - Part I' (2006) 24 Irish Law Times 140; Jonathan Doak, 'Victims' Rights in Criminal Trials: Prospects for Participation' (2005) 32(2) Journal of Law and Society 294, 298-9. Historically, the victim was an active participant in the criminal process. Shane Kilcommins et al, The Victim in the Irish Criminal Process (Manchester University Press, forthcoming 2018) ch 2; Ivana Bacik et al, Report on Services and Legislation Providing Support for Victims of Crime (Trinity College Dublin 2007); Lillian McGovern, 'The Victim and the Criminal Justice Process' in Paul O'Mahony (ed), Criminal Justice in Ireland (IPA 2002) 393.

13 Maguire v Central Mental Hospital [1996] 3 IR 1; Application of Gallagher [1991] 1 IR 31; Re Ellis [1990] 2 IR 291. The exception in relation to legal representation is the Criminal Law (Rape) Act 1981, s 3, as amended by the Sex Offenders Act 2001, s 34, whereby a complainant in a trial for a sexual offence is entitled to legal representation where the defence seeks leave to cross-examine the complainant about her sexual history.

14 Doak (n 11) 244-5. It is salient to acknowledge, at the same time, that a jury's perception of the role of the victim may transcend the law's formal classification. In the reality of courtroom practice, the victim is no ordinary witness and, regardless of the outcome, her evidence may be influential if not decisive. Particularly in cases where the accused elects to testify, the victim's evidentiary function may make her seem to be something close to a party in the mind of the finder of fact. In the absence of empirical research in Ireland on juror perception and adjudication, this is necessarily a matter of speculation. 
prosecution team does not in any way represent the victim. There may be a coincidence of interest and there may not. There can be situations where the interests of the victims as they see them and the interests of the prosecution are diametrically opposed ...15

The prosecution is not obliged to afford the victim an evidentiary voice at trial. In practice of course, victims tend to participate under the umbrella of the prosecution's case in the majority of trials and their evidence may have a decisive effect on the trial and verdict. But, as Mr Justice Carney has indicated, this does not in itself guarantee 'a coincidence of interest' between the victim and the prosecution in the denouement of the giving of evidence.

An extreme example of divergence of interest occurs where a dispute between the victim and the prosecution over the victim's intended evidence escalates to the point where the court allows the prosecution to treat the victim as a hostile witness. ${ }^{16} \mathrm{~A}$ marginally more benign possibility is that the prosecution may ask the court to admit the victim's pre-trial statement in addition to, or in lieu of, testimony, on the ground that she is an uncooperative witness. ${ }^{17}$ These circumstances may be highly exceptional, but they underscore the reality that the giving of evidence is not an autonomous prerogative, but rather is dependent upon the decisions of the parties and the court. Indeed, in theory a victim may be called to testify and compelled to appear even where she does not wish to give evidence or participate in the proceedings in any other way. ${ }^{18}$

There are other procedural and practical limitations that may inhibit active participation at trial above and beyond the victim's dependency on the prosecution. For example, the voice of the victim, like that of any witness, does not sound in a free-flowing narrative, but rather is constrained by the rituals of examination-in-chief and crossexamination. The posing of questions by counsel is inherently directive and at times invariably confrontational. The adversarial approach is assumed to serve the epistemic function of getting to the truth; the very term 'examination' reflects its capacity to probe a factual narrative by testing the witness's account, highlighting matters that are contested between the parties and exposing inconsistencies in the witness's version of events. The interactive exchange that forms the centrepiece of the process requires the witness to provide direct, specific responses to all manner of individual questions within possibly lengthy lines of questioning. The dialogue is buttressed by the broader impression that the exchange makes on the jury and the potentially powerful role of inference in adjudication on the facts.

For some time Irish law has operated some limited rules and procedures that indirectly govern the giving of evidence by victims. However, there is no dedicated statute or case law that expressly governs the evidentiary role of victims. Such rules and

15 Paul Carney, 'The Role of the Victim in the Irish Criminal Process' (2007) Judicial Studies Institute Journal 7, 11.

16 DPP v Cunningham [2007] IECCA 49; People (AG) v Taylor [1974] IR 97; People (AG) v Hannigan [1941] IR 252. Where the court has acknowledged that a witness is hostile, the prosecution assumes the guise of adversarial counsel and may seek to undermine the witness's evidence and credibility through cross-examination.

17 Criminal Justice Act 2006, s 16. Specifically, the prosecution must satisfy the court that the witness is refusing to testify or denies that she made a pre-trial statement or is offering testimony that materially contradicts a pre-trial statement.

18 Liz Heffernan (with Una Ní Raifeartaigh), Evidence in Criminal Trials (Bloomsbury Professional 2014) 18-20. Prosecutorial influence may bear on victim participation in additional less obvious ways. Occasionally, the prosecution may be allowed to present a victim's pre-trial statement as evidence and, of course, the victim's perspective may be heard indirectly through the testimony of other witnesses who appear for the prosecution. Similarly, it is the task of the prosecution to secure the permission of the court where a victim may be eligible for a special evidentiary measure such as video-link. 
procedures as exist regulate the giving of evidence not because the witness is a victim per se, but rather because her position is distinct in some other sense from that of witnesses in general. Special statutory measures have been extended to certain categories of witness, notably children and persons with intellectual disabilities ${ }^{19}$ and witnesses who are subjected to intimidation. ${ }^{20}$ The enactment of these special measures is a reflection of evolving societal attitudes regarding vulnerability coupled with a greater understanding of the trauma that testifying can cause. ${ }^{21}$ This may be particularly true where the individuals in question are not merely witnesses but also victims of the offences for which the accused is being tried. ${ }^{22}$ But where the witness is a victim, her eligibility for special measures turns not on her status as the injured party but rather on her designation within a category that attracts special measures. For example, a child or a person with an intellectual disability who is the alleged victim of a physical or sexual assault is eligible to give her evidence via video-link, through an intermediary or by means of a videorecorded statement because she is a child ${ }^{23}$ or a person with an intellectual disability. ${ }^{24}$ In the majority of cases, the fact that she is a victim is incidental and does not formally trigger the application of the special measure although her experience as a victim of the crime at issue may encourage the trial judge to exercise any discretion at the court's disposal in favour of protection.

The adequacy of the statutory framework for vulnerable witnesses and the efficacy of the existing measures are highly debatable questions. The absence of a cohesive normative vision has stymied the development of a coherent policy agenda; legislative provision for special measures has been influenced by the seemingly interchangeable motives of supporting witnesses, safeguarding the integrity of the evidentiary process and prosecuting particular crimes. ${ }^{25}$ Thus, the enactment of measures and their gradual implementation in the courts has not been driven invariably by the policy of supporting vulnerable witnesses per se or respecting their fledgling right to be heard. ${ }^{26}$

A prominent means whereby a victim's voice can be heard in an Irish courtroom is the delivery of a victim impact statement at the sentencing of a convicted offender. A procedure traditionally exercised exceptionally at the discretion of the judge, the hearing of victim impact evidence was placed on a statutory footing over 20 years ago. ${ }^{27}$ Victim

19 Criminal Evidence Act 1992, Part III.

20 Criminal Justice Act 1999, s 39.

21 See Adrian Keane, 'Cross-Examination of Vulnerable Witnesses - Towards a Blueprint for Reprofessionalisation’ (2012) 16 International Journal of Evidence and Proof 175; Mandy Burton et al, 'Implementing Special Measures for Vulnerable and Intimidated Witnesses: The Problem of Identification' [2006] Criminal Law Review 229; Jonathan Doak (n 11) 306; Ellison (n 2).

22 The psychological trauma that testifying in open court would cause to a victim of a violent or sexual offence, for example, is a possible ground on which a trial judge might exercise her statutory discretion to permit the use of video-link to support a witness: Criminal Evidence Act 1992, s 13(1)(b); O’D v DPP [2015] IECA 273; DPP v McManus [2011] I ECCA 32.

23 Criminal Evidence Act 1992, s 13(1)(a), s 14 and s 16(1)(b).

24 Ibid s 19.

25 Donnelly v Ireland [1998] 1 IR 321 (SC); White v Ireland [1995] 2 IR 268 (HC); Special Rapporteur on Child Protection, Geoffrey Shannon, Second Report to the Oireachtas (October 2008); Law Reform Commission, Report on Child Sexual Abuse (LRC 32-1990) and Report on Sexual Offences against the Mentally Handicapped (LRC 331990).

26 For example, trial judges retain a discretion to caution juries about the risks of relying on a child's testimony if it is uncorroborated, a legacy of the scepticism with which children's evidence was approached by the historical common law: Criminal Evidence Act 1992, s 28.

27 Criminal Justice Act 1993, s 5. A new s 5, incorporating amendments, was substituted by the Criminal Procedure Act 2010, s 4. 
impact statements facilitate participation by allowing the victim an opportunity to give a subjective narrative account of the effect that the offence has had on her. The statement also provides the court with an evidentiary basis on which to take the victim's perspective into account when sentencing. Because the sentencing decision rests firmly in the hands of the judge and the evidence of victim impact is just one factor that the judge must take into account, the procedure is generally perceived as less controversial than victim participation at trial. ${ }^{28}$

At the same time, it is apposite to acknowledge that victim impact evidence is circumscribed under Irish law and practice in a number of respects. The first and most obvious limitation is that the opportunity to participate in this way arises only at sentencing and thus does not avail a victim where a case does not go to trial or results in the dismissal of the charges or the acquittal of the accused. Second, victim impact statements are confined under the existing law to sexual offences and violent offences and are not generally available in other proceedings. Third, a victim for purposes of impact evidence at sentencing is relatively narrowly defined as a person who has been harmed directly by the offence. Thus, a family member of a direct victim is entitled to make a statement only where the direct victim has died, is ill or is otherwise incapacitated as a result of the offence.

\section{The Directive}

The term 'participation' is not defined in the Directive and apparently symbolises a broad entitlement that encapsulates certain specific, limited rights. Chapter 3, which is styled 'Participation in Criminal Proceedings', comprises the following concrete entitlements: the right to be heard; ${ }^{29}$ rights in the event of a decision not to prosecute; 30 the right to safeguards in the context of restorative justice services; ${ }^{31}$ the right to legal aid; ${ }^{32}$ the right to reimbursement of expenses; ${ }^{33}$ the right to the return of property; ${ }^{34}$ the right to a decision on compensation from the offender in the course of criminal proceedings; $; 5$ and the rights of victims resident in another member state. ${ }^{36}$ Participation, it seems, is not a self-standing, justiciable right but rather a broad canvas for these specific, limited entitlements. The variation in the nature and rigour of the rights listed in Chapter 3 represents an additional limitation. Some of the listed rights, such as the right to legal aid, apply only in those member states where the victims have 'the status of parties to criminal proceedings' and, even then, the conditions and procedures that govern access are stated to be a matter for national law. The Directive's nomenclature is misleading in so far as important provisions relating to victim participation are housed not only in Chapter 3 but also in Chapter 4, which is titled 'Protection of Victims and Recognition of Victims with Specific Protection Needs' and which includes special measures that can and should be available to victims at trial. Finally, it is noteworthy that the Directive's stipulations on the provision of information to victims are also relevant in so far as they facilitate both active and passive participation in the proceedings as a whole.

28 See generally, Thomas O’Malley, Sentencing Law and Practice (3rd edn, Thomson Round Hall 2016) 290-1. 
The concept of victim participation and its application within national legal systems varies across the EU. ${ }^{37}$ The equivocation of the EU legislature over the idea of harmonising disparate national approaches to victim participation is reflected in the ambiguous language employed in the Directive. Whereas the provisions on victim support are prescriptive for the most part, the legislative approach to participation is more descriptive and aspirational. Participation is an area where the Directive sets 'minimum rules' in the literal sense of the lowest common or accepted practice among the member states. Moreover, the EU legislature has afforded member states a wide margin of appreciation in the transposition of these provisions. ${ }^{38} \mathrm{It}$ is seeking neither to standardise the national systems nor to substantially alter particular models of criminal justice. This is understandable given the limits of EU competence in the field of criminal justice and the sensitivities that would surround any radical reform by dint of mandatory harmonisation. A potential clawback on this minimalist approach is the statement in Recital 11 that the Directive's minimum rules do not stifle the freedom of member states to afford victims more extensive recognition and protection. This allows for the possibility that the incremental augmentation of entitlements in member state practice may coalesce over time into a broader and more robust understanding of victim participation as a matter of national and European law.

The wide variation in the exercise of a victim's right to participate from one member state to another and the relatively low bar on transposition are difficult to reconcile with the Directive's ambitions for harmonisation and equal treatment for victims across the member states. It is and will remain the case that a victim's entitlement to participate and her experience of participation will depend to a considerable extent on her geographical location within the EU. It is appropriate in this regard to de-couple participation from the other areas of the Directive - information, support and protection - where greater uniformity in national law and practice is a boon to convergence. Even so, it is possible to identify the emergence in the Directive of certain minimum, harmonising standards that are likely to characterise future practice in Ireland and elsewhere. The remainder of the present discussion will focus on two emerging participatory rights: first, a right on the part of a victim to be heard during the course of the trial process; and, second, a right to protection from harm caused by the process itself. These fledgling participatory rights are distinct but related and consequently are dealt with interchangeably in both the Directive and the Victims of Crime Bill.

\section{The right to be heard}

Arguably, the most significant dimension of victim participation under the Directive is the right to be heard, which Article 10 expressly guarantees in the following terms:

1. Member States shall ensure that victims may be heard during criminal proceedings and may provide evidence. Where a child victim is to be heard, due account shall be taken of the child's age and maturity.

2. The procedural rules under which victims may be heard during criminal proceedings and may provide evidence shall be determined by national law.

On its face Article 10 implies a broad principle that might apply to victims of any crime and throughout the process. However, the interpretative waters surrounding the right to be heard are muddied by commentary in the supporting texts. For example, Recital 41

37 See generally Jackson and Summers (n 2) chs 2 and 3; Andrea Ryan, Towards a System of European Criminal Justice: The Problem of Admissibility of Evidence (Routledge 2014); Doak (n 12) 294.

38 Directive, Recital 20; DG Justice Guidance Document (n 4) 4. 
states: 'The right of victims to be heard should be considered to have been fulfilled where victims are permitted to make statements or explanations in writing.' In contrast, the European Commission has adopted a more flexible stance:

... this right may range from basic rights to communicate with and supply evidence to a competent authority to more extensive rights such as a right to have evidence taken into account, the right to ensure that certain evidence is recorded, or the right to give evidence during the trial. ${ }^{39}$

The overall thrust of the textual guidance is that the Directive's minimum rules on victim participation will be met where member states are affording victims some opportunity to be heard at any stage in the criminal process. This interpretation is consistent with the understanding of the right under Council Framework Decision 2001/220/JHA on the standing of victims in criminal proceedings which the Directive replaced. ${ }^{40}$ In that context, the Court of Justice recognised that member states enjoy considerable discretion when implementing mechanisms and procedures to give effect to the right. ${ }^{41}$ Thus, the right to be heard is more variable and less robust than a literal reading of Article 10 would suggest.

A notable aspect of Article 10 is the inclusion of an express obligation on member states to ensure that victims 'may provide evidence'. Intriguing questions surround the nature and extent of a victim's entitlement to provide evidence and the relationship between the concepts of being heard and providing evidence. The structure of Article 10(1) implies that a victim's entitlement to provide evidence forms a single albeit significant strand within the broader right to be heard; giving evidence, in other words, constitutes one of the ways in which a victim may be heard. However, this interpretation risks rendering superfluous the reference to providing evidence. A plausible import of the conceptual distinction is simply its effect in ensuring that the information victims convey to national authorities plays a formal role in the process, namely, that it is included in the evidence that may influence adjudication on the offence with which the accused is charged. ${ }^{42}$ So read, the language relating to providing evidence may safeguard against national practices that pay lip service to the right to be heard.

\section{The right to protection}

Contemporary research that has shone a light on the adversarial process casts some doubt on the ability of vulnerable witnesses, in particular, to provide complete and accurate evidence under these conditions. ${ }^{43}$ For the victim, as well as the parties and the court, furthering the epistemic goal of providing one's 'best evidence' may be an important or even defining characteristic of participation. If we take the view that victim participation serves other purposes, such as personal dignity and rehabilitation, then the suitability of the adversarial approach becomes even more problematic. Putting aside testimony's truthseeking function, it is questionable whether examination is an appropriate much less ideal means of allowing any particular victim to participate in the sense of being heard during the trial phase. Respecting the dignity and well-being of a victim who testifies should be an imperative in all cases, but it is an acute concern when the nature of the offence or the

39 DG Justice Guidance Document (n 4) 29.

40 OJ L 82/1, 22/3/2001. Art 3 stated: 'Each Member State shall safeguard the possibility for victims to be heard during proceedings and to supply evidence.'

41 Case C-404/07, Katz, 9 October 2008, [2008] ECR I-7607; Case C-507/10, Bernardi [2011] ECR I-14241; Case C-105/03, Pupino, 16 June 2005, [2005] ECR I-5285.

42 SN v Sweden (2004) 39 EHRR 13, para 45 (recognising that a person is a witness where she has given statements to the police that were used in evidence by the domestic courts).

43 See (n 21). 
victim's personal circumstances compound the inherently difficult process of responding to confrontational questioning in open court.

One of the Directive's salutary advances is an express commitment to shielding victims and their family members from secondary and repeat victimisation, from intimidation, and from retaliation either by the alleged offender or more generally as a consequence of participating in criminal proceedings. ${ }^{44}$ Protection of a victim's safety and dignity from these sources of harm is established as a matter of right under Article 18. Crucially, the concept of harm includes 'the risk of emotional or psychological harm' and the scope of protection extends to 'the dignity of victims during questioning and when testifying, ${ }^{45}$

Article 18 is reinforced by the general duty in Article 1 to 'ensure that victims are recognised and treated in a respectful, sensitive, tailored, professional and nondiscriminatory manner', and it is buttressed by further specific recognition of the right to privacy in this context. ${ }^{46}$ The dignity right of a victim who gives evidence constitutes a weighty guarantee that operates hand-in-glove with the right to be heard and the right of victims with protection needs to special measures at trial. It also reflects a symbiosis between EU law and the ECHR in so far as the European Court of Human Rights has acknowledged the importance of protecting victims in particular trial contexts, notably proceedings for sexual offences, especially where the victim is a child. ${ }^{47}$ Drawing on the right to respect for personal integrity, the court has observed that:

. . criminal proceedings should be organised in such a way as to not to unjustifiably imperil the life, liberty or security of witnesses, and in particular those of victims called upon to testify, or their interests coming generally within the ambit of Article 8 of the Convention. ${ }^{48}$

This challenging objective of safeguarding the dignity of victims who give evidence necessitates multi-faceted endeavour on the part of national authorities. Article 18 embodies a commitment to protect victims from the criminal justice system itself by ensuring that participation in criminal proceedings will not be a source of undue harm. The trauma that some victims experience as witnesses is widely acknowledged, but it has tended to be tolerated as an inevitable side-effect of the adversarial system of justice. For complainants of sexual offences, the distress engendered by the experience of testifying in court can be particularly acute. Thus, Article 18 is important for its express acknowledgment that the dignity of victims is a factor that lawmakers, courts and other decision-makers must take into account.

At the same time, the content of a dignity right for victims and the legal consequences that may flow from its recognition remain uncertain. The wording of Article 18 might be construed as imposing no more than a limited obligation on national authorities to ensure that some measures are available to protect the dignity of victims during questioning and when testifying. So read, the provision affords the victim an objective right to generic measures, if applicable, as opposed to a subjective right to protection from all forms of harm. The state might argue further that a right in the style of Article 18 is necessarily

44 Directive, Recitals 52 and 53.

45 See also DG Justice Guidance Document (n 4) 39-40. This is supported by Directive, Article 20, which affords certain specific safeguards including protection against unjustified delay in the conduct of interviews and an entitlement to be accompanied by a legal representative.

46 Directive, Article 21.

47 SN v Sweden (n 42) para 47; V ronchenko v Estonia, App no 59632/09, 18 July 2013 (First Section), para 56.

48 Y v Slovenia (2016) 62 EHRR 3, para 103. 
qualified by considerations of reasonableness and practicality, caveats that resonate in the unpredictable setting of the criminal trial. At this stage in the evolution of European criminal justice, the significance of participatory rights remains subtle but heady. Article 18 may signal a shift in legal culture, but its realisation will necessitate the implementation of concrete measures and the allocation of resources in practice.

The right of a victim to protection during the course of a trial is necessarily circumscribed by the constitutional and human rights imperative of ensuring that the accused receives a fair trial. Article 18 is one of just a handful of provisions in the Directive that expressly acknowledges that the member states' obligation shall operate 'without prejudice to the rights of the defence'. ${ }^{49}$ This language serves as a valuable reminder that both the design and delivery of measures to protect the dignity of victims must respect the many and varied rights of the accused under the Irish Constitution and international human rights law. As the European Court of Human Rights has put it: 'principles of fair trial require that in appropriate cases the interests of the defence are balanced against those of witnesses or victims that are called upon to testify'. ${ }^{50}$ The implication is that special measures will be compatible with the ECHR only where they can be reconciled in principle and in practice with 'the adequate and effective exercise of the rights of the defence'. 1

\section{Transposing participatory rights}

Bearing in mind the structural obstacles to victim participation in the adversarial trial system and the robust constitutional commitment to safeguarding the rights of the defence, it is perhaps not surprising that the Irish government has eschewed dramatic reform and opted for a series of discrete proposals. A consequence is that the Victims of Crime Bill fails to replicate the Directive's substance and symbolism on the core concepts of 'participation', 'being heard' and 'dignity'. Indeed, the absence of these terms within the proposed statutory language underscores an essentially functionalist approach to transposition of this aspect of the Directive.

In Ireland, victims may have the opportunity to participate in criminal proceedings in three principal ways: reporting an alleged offence to the Gardaí, testifying at trial and, delivering a victim impact statement at sentencing. The Bill purports to strengthen each of these dimensions of victim participation through a bevy of specific statutory provisions, most of which take the form of amendments to existing legislation. These proposals are welcome in substance and, if enacted, will enhance the range and depth of opportunities for victims to participate in the trial process. However, the proposals are inhibited by their form because most of the intended amendments would extend the already complicated existing legislation and the overall effect is likely to hamper the accessibility of victims' participatory rights.

An area where the proposed legislation is likely to influence the ability of victims to provide evidence relates to the giving of pre-trial statements to Gardaí. These statements serve a significant investigative function and, where a case goes to trial, they are disclosed to the other side and may assist both the parties and the witness herself when preparing for trial. Their use by counsel as a tool to test the credibility of the witness during cross-

49 The other provisions that contain this qualifying language are Art 7 (right to interpretation and translation), Art 20 (right to protection during criminal investigations) and Art 23 (right to protection during criminal proceedings). The premise that the rights in the Directive are without prejudice to the rights of the defence is arguably implicit throughout the Directive. See Directive, Recital 12.

50 Doorson $v$ The Netherlands (1996) 22 EHRR 330, para 70.

$51 S N v$ Sweden (n 42) para 47; Vronchenko v Estonia (n 42) para 56. 
examination is long-standing and legendary. ${ }^{52}$ Moreover, in recent years, the Oireachtas has sanctioned the limited admission of witness statements as independent evidence by dint of exceptions to the rule against hearsay. 53

Against the backdrop of this trend, the Bill takes the noteworthy step of formalising the interaction between victims and the Gardaí during the investigative stage that leads to the gathering and recording of such evidence. Whereas Part 2 of the Bill delineates a comprehensive obligation on the part of the Gardai to furnish victims with information relevant to the process, Part 3 contains a number of disparate provisions, for example, relating to the making of complaints by victims ${ }^{54}$ and the conduct of interviews between victims and the Gardaí. ${ }^{55}$ At the heart of the new regime is a requirement that the Gardai assess each individual victim pursuant to $\mathrm{s} 14$. The purpose of the assessment is to identify the protection needs, if any, of the victim ${ }^{56}$ and to ascertain whether and to what extent she might benefit from special measures during the investigation and/or at trial. ${ }^{57}$ It is salient to note that a special measure, whether theoretically applicable during the investigation or at trial, may be withheld on strikingly open-ended grounds such as potential prejudice to a criminal investigation, criminal proceedings or the administration of justice. ${ }^{58}$ This sweeping proviso could have the practical effect of reversing the benefits of an individual assessment and a direction for special measures.

The cornerstone of the Bill's approach to participation is to extend the concept of special measures to victims who give evidence at trial. The suite of proposed provisions would authorise trial judges to apply the special measures contained in Part III of the Criminal Evidence Act 1992 to victims who have been identified as having special protection needs. Victims would not be entitled to special measures simply because they are victims, but rather on the basis of the trial judge's determination that they are particularly vulnerable to secondary and repeat victimisation, intimidation and retaliation. ${ }^{59}$ Included in a list of mandatory matters that would inform the trial judge's determination are the nature and circumstances of the offence and the personal characteristics of the victim. ${ }^{60}$

Part III currently applies only where the accused is charged with one of a list of violent or sexual offences ${ }^{61}$ that are referred to collectively as 'relevant offences' under the Bill. Part III provides heightened protection to witnesses who are children or persons

52 Heffernan (n 18) 189-93.

53 Notably under Criminal Justice Act 2006, s 16, and Criminal Evidence Act 1992, s 16(1)(b).

54 The statement may be made orally or in writing, including by electronic means, and may be made by the victim or by another person: s 2(1). When making a complaint, the victim may be accompanied by a person of her choice including a legal representative. The Gardaí must furnish the victim with a written acknowledgment of the complaint: s 11.

55 For example, interviews should be held as soon as is practicable (s 13(1)(b)) and the victim may be accompanied by a person of her choosing including a legal representative (s 13(2)). In the case of victims with special protection needs, interviews should be conducted by specially trained personnel and in premises designed or adapted for that purpose (s 14(1)).

56 The statutory language is circular in so far as the term 'specific protection need' is defined as 'a particular need of a victim which is identified by an assessment': $\mathrm{s} 2(1)$.

57 Bill, s 14(1). 'Secondary victimisation' is defined as 'victimisation that occurs indirectly through the response of institutions and individuals to the victim': $\mathrm{s} 2(1)$.

58 Bill, s 16(2).

59 Bill, s 26(d) inserting a new s 14A into the Criminal Evidence Act 1992.

60 Bill, s 26(d) inserting a new s 14B into the Criminal Evidence Act 1992.

61 Criminal Evidence Act 1992, s 12 as amended. 
with intellectual disabilities. ${ }^{62}$ There is a presumption in favour of these witnesses testifying through a live television $\operatorname{link}^{63}$ and they may be eligible for other measures, specifically: receiving questions through an intermediary; ${ }^{64}$ avoiding any need to identify the accused at trial; 65 and giving evidence-in-chief by means of a pre-recorded statement. ${ }^{6}$ Other witnesses who give evidence in proceedings for violent or sexual offences are afforded far less protection at trial. Very exceptionally, and at the discretion of the trial judge, they may to testify via video-link ${ }^{67}$ and avoid having to make an incourt identification of the accused. ${ }^{68}$ However, they are not eligible for the other special measures under Part III that facilitate the giving of evidence by children or persons with intellectual disabilities. ${ }^{69}$ The broad area of special measures for vulnerable witnesses has recently been expanded through the enactment of the Criminal Law (Sexual Offences) Act 2017. The new provisions, which apply in violent and/or sexual offences, include provision for the use of screens in courtrooms and a prohibition on personal crossexamination by the defendant in certain circumstances. ${ }^{70}$

The Bill purports to preserve these existing provisions that apply to witnesses in trials for relevant offences and, at the same time, to establish parallel streams within Part III that would govern special measures for victims. When combined with the recent amendments occasioned by the Criminal Law (Sexual Offences) Act 2017, the proposed rewriting of Part III creates a statutory maze that is likely to be difficult to navigate. Following enactment, the eligibility of a witness for any particular special measure will depend upon a series of distinctions based on the status and personal characteristics of the person giving evidence and the nature of the offence. However, the provisions in the Bill are not structured around these conceptual streams of eligibility: Part III houses distinct sections for each individual special measure and the Bill simply adds subsections to each existing section. To take one example, a person may be eligible for a particular special measure because she is a child and is testifying in respect of a relevant offence, or she may be eligible on the separate basis that she is a child and a victim of an offence. She could not be eligible simultaneously under both streams, although this may be a formalistic limitation because the level of protection is largely the same under the respective streams. The clarity and accessibility of the legislative text is undermined because each and every section must be carefully parsed in order to determine a person's eligibility for special measures.

62 The statutory term employed in s 19 is persons with 'mental handicap'. The Bill, s 26(i), would substitute the term 'mental disorder' as defined by Criminal Justice Act 1993, s 5.

63 Criminal Evidence Act, s 13(1)(a) and s 19. Neither judges nor lawyers may wear wigs or gowns while either category of witness is testifying via video-link: Criminal Evidence Act, s 13(3).

64 Criminal Evidence Act, s 14 and s 19.

65 Criminal Evidence Act, s 18 and s 19.

66 Criminal Evidence Act, s 16(1)(b) and s 19. This particular measure is subject to statutory conditions including the availability of the witness at trial for purposes of cross-examination.

67 Criminal Evidence Act, s 13(1)(b). No statutory guidance is offered as to the factors that should or might influence the exercise of the trial judge's discretion.

68 Criminal Evidence Act, s 18.

69 Some limited measures may apply under other statutes. For example, a witness may testify via video-link under Criminal Justice Act 1999, s 39, if the court is satisfied that she is being intimidated. A witness statement may be admissible in lieu of examination-in-chief under Criminal Justice Act 2001, s 16, if the witness refuses to testify, denies making the statement or gives testimony that is materially inconsistent with the statement.

70 Criminal Law (Sexual Offences) Act 2017, s 36, inserting a new s 14A and s 14C into the Criminal Evidence Act 1992. The sections in question have not entered into force. 
So what does the proposed legislation promise in terms of victim participation at trial? With the leave of the court, a victim of any offence who has been identified as having special protection needs would be able to testify via video-link from a location outside the courtroom ${ }^{71}$ or from behind a screen or other similar device. ${ }^{72}$ In addition, a victim who testified through either medium could avoid having to make an in-court identification of the accused..$^{73} \mathrm{~A}$ child victim or a victim with an intellectual disability could potentially avail of the additional special measures of receiving questions through an intermediary ${ }^{74}$ and giving evidence in-chief by means of a pre-trial statement. ${ }^{75}$ The Bill also proposes a prohibition on the wearing of wigs and gowns by judges and lawyers when a child victim or a victim with an intellectual disability is giving her evidence. ${ }^{76}$

Unfortunately, whereas the Directive designates child victims as presumptively in need of special protection, it applies no corresponding assumption to victims with intellectual disabilities. The EU legislature has acknowledged that victims with disabilities should benefit from protection 'on the same basis as others' ${ }^{77}$ but, at the same time, disability is merely as one of several features that might necessitate the application of special measures during an investigation or at trial. ${ }^{78}$ That said, the Directive has the merit of a broad understanding of disability that contrasts with the narrow and more antiquated approach of the traditional Irish legislation. If lawyers and judges actively recognise disability as a factor influencing the use of special measures under the proposed regime, then a broader range of persons with disabilities may benefit in practice than under existing legislation. However, it would be preferable if the Bill were amended to fill this procedural lacuna by including a presumption that a victim with intellectual disabilities has special protection needs and consequently would benefit from special measures.

The final way in which the Bill seeks to enhance victim participation is by expanding the current regime governing victim impact evidence at sentencing. Section 27 purports to build on the existing statutory foundation by extending the facility of victim impact statements beyond the current contexts of sexual or violent offences. The result is that the direct victim of any offence would have the option of delivering a statement to the sentencing court, a move that could result in victim evidence becoming a routine feature of sentencing across the gamut of criminal practice. The Bill does not disturb the other features of the existing legislation such as the possibility of a family member delivering a statement in certain defined circumstances and the entitlement of some victims, notably a child or a person with an intellectual disability, being heard via video-link. ${ }^{79}$

It is salient to note that participation through victim impact evidence is not mandatory; the statutory requirement that the victim apply to the court in order to be heard reflects the reality that not every victim will wish to give evidence. The procedure assumes that the victim is aware of her right to participate and is ready and able to make the necessary application. ${ }^{80}$ The emphasis within the EU Directive and the Bill on the

71 Bill, s 26(b), inserting a new s 13(1A) into the Criminal Evidence Act 1992.

72 Bill, s 26(d), inserting a new s 14A(2)(b) into the Criminal Evidence Act 1992.

73 Bill, s 26(h), amending s 18 of the Criminal Evidence Act 1992.

74 Bill, s 26(c), inserting a new s 14(1A) into the Criminal Evidence Act 1992.

75 Bill, s 26(f), amending s 16(1)(b)(i) of the Criminal Evidence Act 1992.

76 Bill, s 26(d) inserting a new s 14C into the Criminal Evidence Act 1992.

77 Directive, Recital 15.

78 Directive, Recital 56.

79 Criminal Justice Act 1993, s 5 as amended.

80 Bacik et al (n 12) 44. 
provision of information to victims may bolster the position of the victim in this regard. Under s 6, one of the items of information of which the Gardaí are obliged to inform a victim on first contact is 'a victim's right to give evidence or make submissions under section 5 of the Act of 1993 '. ${ }^{1}$

\section{Concluding remarks}

In Ireland, victims may participate in criminal proceedings in various ways, notably reporting an alleged offence, testifying at trial and delivering a victim impact statement at sentencing. These indicia of participation tend to be viewed as disparate aspects of the process and each is subject to its own inherent limitations. The Directive, and its transposition in the form of primary legislation, signals an increasing need to perceive criminal justice as a seamless process that spans the investigative, trial and post-trial phases. The overarching principle is that victims should be treated throughout the process 'in a respectful, sensitive, tailored, professional and non-discriminatory manner' by the relevant authorities. ${ }^{82}$ Indeed, this principle should govern state interaction with all individuals involved in the process including persons suspected of crime or charged with offences and witnesses other than victims who report wrongdoing or provide evidence.

The inclusion within the Directive of a right to participate invites reflection on the role of the victim in criminal justice from the standpoint of theory, policy and practice. The co-existence of the emerging participatory rights of victims and the established rights of the defence is a complex issue that will necessitate careful, considered judicial development. The principle that a person who is accused of crime is entitled to a trial that is fair overall is a mainstay in our systems of criminal justice and human rights. At the same time, the notion of 'fairness' has evolved to a degree in tandem with developments in societal understanding of the experience of victims and other witnesses who participate in the trial process. This trend finds expression, for example, in the heightened profile of special measures at trial and a corresponding diminution in the prevalence of confrontation between the accused and the victim in open court. The Directive and the Bill take up their place at a sub-constitutional level, and for their part reflect an emerging fluidity within the rights equilibrium.

The common law trial process has become a highly regulated enterprise and, as the changes discussed in this article suggest, trial judges will be called upon to play an expanded role in supervising the presentation of evidence. The time is ripe in Ireland to explore comparative common law experience and consider, in particular, the development of pre-trial protocols that might constructively assist all actors in preparing for trial. Reconciling rights and protecting distinct interests requires a delicate balance that should be informed by ongoing policy debate and close monitoring of developments in practice.

81 Bill, s 6(1)(j). The Gardaí are further obliged, under s 7, to inform a victim of her right to request information at various stages of the criminal process including the date of sentencing: Bill, s $7(2)(\mathrm{g})(\mathrm{i})$. Similarly, a victim is entitled to request a copy of any victim impact statement or submission she has made, $s$ 7(2)(b)(ii).

82 Directive, Art 1 and Recital 9. 